African Crop Science Journal by African Crop Science Society is licensed under a Creative Commons Attribution 3.0 Uganda License. Based on a work at www.ajol.info/ and www.bioline.org.br/cs DOI: http://dx.doi.org/10.4314/acsj.v24i1.6

\title{
EFFECT OF MAIZE INTERCROP PLANT DENSITIES ON YIELD AND $\beta$-CAROTENE CONTENTS OF ORANGE-FLESHED SWEETPOTATOES
}

\author{
A. ASIIMWE ${ }^{1,2}$, I.M. TABU ${ }^{1}$, B. LEMAGA ${ }^{3,4}$ and S. TUMWEGAMIRE ${ }^{3,5}$ \\ ${ }^{1}$ Department of Crops, Horticulture and Soils, Faculty of Agriculture, Egerton University \\ P. O. Box 536, Njoro, Kenya \\ ${ }^{2}$ Current address: National Crops Resources Research Institute, P. O. Box 7084 Kampala, Uganda \\ ${ }^{3}$ International Potato Center (CIP), P.O. Box 22274, Kampala, Uganda \\ ${ }^{4}$ Current address: Agricultural Transformation Agency (ATA), Jomo Kenyatta Road, Zequala Towers, \\ $7^{\text {th }}$ Floor, Addis Ababa, Ethiopia \\ ${ }^{5}$ Current address: International Institute of Tropical Agriculture (IITA), P. O. Box 34441, \\ Dar es Salaam, Tanzania \\ Corresponding author: s.tumwegamire@ cgiar.org
}

(Received 27 May, 2015; accepted 12 February, 2016)

\begin{abstract}
Despite efforts to demonstrate the value of orange-fleshed sweetpotato (OFSP) (Ipomoea batatas L.) and quality protein maize (Zea mays L.) in combating vitamin A and protein malnutrition, small land holdings by rural poor farmers still limit the crops' overall production in Africa. As such, intercropping and optimum plant density in cropping systems will help farmers to improve productivity of the crop, and hence, improve household food and nutrition security. This study determined the effect of maize plant population, in a sweetpotato-maize intercrop, on yields and $\beta$-carotene content of two popular OFSP cultivars, Ejumula and NASPOT 9 O (Kabode). Each variety was intercropped with maize variety Longe 5, at three plant densities (i.e. 41,666, 55,555 and 88,888 plants ha $^{-1}$ ), at Ngetta Zonal Agricultural Research and Development Institute in Uganda. While 55,555 plants of each OFSP cultivar were used for both sole and intercrops, the sole maize plot was 44,444 plants ha ${ }^{-1}$. Maize and sweetpotato were harvested at 120 and 135 days after planting, respectively. $\beta$-carotene content and yield in sweetpotato roots were significantly $(\mathrm{P}<0.05)$ reduced by high maize density. Irrespective of maize density, NASPOT $9 \mathrm{O}$ produced more root yields than Ejumula. Land Equivalent Ratios of $>1.2$ were obtained at maize intercrop densities of 41,666 and 55,555 plants ha $^{-1}$.
\end{abstract}

Key Words: Ipomoea batatas, land equivalent ratio, Zea mays

\section{RÉSUMÉ}

Malgré les efforts visant à démontrer la valeur nutritionnelle en combinaison de la patate douce à chaire orange (OFSP) (Ipomoea batatas L.) et du maïs à grande valeur proteique (Zea mays L.) dans la lutte contre la malnutrition liée au manque de la vitamine A et de proteine, les petits producteurs Africains continuent de limiter les rendements de leur cultures. A cet effet, l'association des cultures doublée d'une densité optimale des plants dans les systems de cultures, aiderait les producteurs à améliorer les rendements de leurs cultures et par consequent améliorer la qualité de vie dans les ménages et assurer la sécurité alimentaire. La présente étude a détérminé l'effet de la densité des plants de maïs, dans une culture associée avec la patate douce sur le rendements et la teneur en b-carotene de deux variétés populaires de patate douce OFSP, Ejumula et NASPOT 9 O (Kabode). Chaque variété a été plantée en association avec la variété de maïs Longe 5, à trois différentes densités (i.e. 41,666, 55,555 et 88,888 plants ha${ }^{1}$ ), et ceci à l'Institut Zonale de Developpement et de Recherche en Agriculture de Ngetta en Ouganda. Pendant 
que la densité 55,555 plants de chaque variété de OFSP a été utilisé dans la culture solitaire et en association, la culture solitaire de maïs était à 44,444 plants ha ${ }^{-1}$. Maïs et patate douce ont été récoltés respectivement à 120 et 135 jours après. La teneur en $\beta$-carotene et le rendement en tubercules de patate douce ont été réduits de façon significative $(\mathrm{P}<0.05)$ par une densité forte de maïs. Quelle que soit la densité de maïs, NASPOT $9 \mathrm{O}$ a produit plus de tubercules qu'Ejumula. Le ratio équivalent était $>1.2$ pour une densité de maïs de 41,666 et 55,555 plants ha $^{-1}$, en culture d'association.

Mots Clés: Ipomoea batatas, ratio équivalent, Zea mays

\section{INTRODUCTION}

Sweetpotato (Ipomoea batatas L.) ranks third among the staple crops in Eastern and Central Africa sub-region (CIP, 2015). It is a preferred disaster mitigation crop because it is hardy, easy to grow and matures in a short time (Odongo et al., 2007). Traditionally, sweetpotato production in Uganda and neighbouring countries, has been based on white-fleshed varieties, which have low or no $\beta$-carotene (Low et al., 2001). However, orange-fleshed sweetpotato (OFSP) varieties, rich in $\beta$-carotene, a precursor to vitamin $\mathrm{A}$, have been identified and demonstrated to combat vitamin A deficiency (VAD) (Van Jaarsveld et al., 2005; Low et al., 2007); and are being strongly promoted in Eastern Africa (Tumwegamire et al., 2004). Vitamin A deficiency is prevalent in Uganda, with $38 \%$ of children and $36 \%$ women reportedly affected (UBOS and ICF International Inc., 2012). Severe VAD causes blindness, premature death, lowers disease resistance in children and reduces survival of mothers during childbirth (Frossard et al., 2000).

Maize (Zea mays L.) is also one of the major staple food crops in countries like Uganda, ranking fourth after plantain, cassava and sweetpotato (FAO, 2010). Conventional white maize is unfortunately deficient in protein because of the limiting quantities of essential amino acids: lysine and tryptophan (Vasal, 2001). As such, the large percentage of the population in developing countries who depend on maize, are exposed to protein or essential amino acid deficiencies and associated ailments (Krivanek et al., 2007). Quality protein maize (QPM) has twice the amount of limiting amino acids- lysine and tryptophan contents compared to conventional maize (Krivanek et al., 2007), and is thus being promoted to combat protein malnutrition in humans.
Bio-fortified crops like QPM and OFSP were introduced in Uganda, but one of the challenges to their wide adoption is shortage of land due to the increasing human population (UBOS, 2007), which impedes expansion of other crop varieties as well. In such situations, intensive cropping practices such as intercropping are recommended (Lithourgidis et al., 2011).

Traditionally, sweetpotato has been grown as an intercrop with beans, cassava, maize and pigeon pea (Bashaasha et al., 1995; Gibson, 2006). Yields of crops in intercrops have been reported to fluctuate with component crop populations (Egbe and Idoko, 2009; Ossom et al., 2009; Ossom, 2010). A maize-sweetpotato intercrop with $50 \%$ of the recommended maize plant population, gave the highest yield, while the other mixtures with more or less maize gave less maize yields (Oswald et al., 1996). However, sweetpotato root yield was reduced.

A different intercrop study reported that sweetpotato yield was reduced by up to $56 \%$, while maize yields were not affected (Webi, 2007).

In Uganda, yield responses of either OFSP or QPM under intercropping are not known. Research on sweetpotato elsewhere indicated a cultivar- and location-dependent response to intercropping (Oswald et al., 1996). In a study by Oswald et al. (1995a), shade induced by a mesh affected sweetpotato root yield, although the effects were variety dependent. Further, the effect of intercropping on $\beta$-carotene content and yield in OFSP is not known.

This study was, therefore, designed to investigate the productivity of OFSP varieties and QPM in intercrop at varying plant densities of the latter and to determine the effect of intercropping on $\beta$-carotene content and yield of OFSP. 


\section{MATERIALS AND METHODS}

A study was conducted at Ngetta Zonal Agricultural Research and Development Institute (Ngetta ZARDI) in northern Uganda, during the first (April-June) and second (July-October) rains of 2011. Ngetta ZARDI is found at an altitude of $1091 \mathrm{~m}$, latitude $2^{\circ} 17^{\prime} \mathrm{N}$ and longitude $32^{\circ} 56^{\prime} \mathrm{E}$. It has a temperature range of 22.5 to $29{ }^{\circ} \mathrm{C}$ and bimodal rains, amounting to 1200 to $1600 \mathrm{~mm}$ per annum. The soils are sandy clay loam, classified as Ferralsols.

Two OFSP varieties, Ejumula and NASPOT 9 $\mathrm{O}$, and one quality protein maize variety (Longe 5) were used in the study. On plots measuring 4.5 $\mathrm{m}$ long by $4.8 \mathrm{~m}$ wide, each OFSP variety was planted on four ridges each measuring $4.5 \mathrm{~m}$ long and $1.2 \mathrm{~m}$ wide. On each ridge, two rows of vines were planted at a spacing of $0.3 \mathrm{~m}$ by $0.3 \mathrm{~m}$, giving 55,555 plants per ha. Maize was intercropped with each of the sweetpotato varieties, except in the sole sweetpotato and maize check plots. Maize in the intercrops was planted in furrows between the ridges, at three different plant densities. Plant density 1 , where one row of maize, was planted with one seed per hill at $0.25 \mathrm{~m}$ inter-row spacing, giving 41,666 plants ha ${ }^{-1}$; plant density 2 where one row of maize was planted with two seeds per hill at $0.375 \mathrm{~m}$ intra-row spacing giving 55,555 plants ha ${ }^{-1}$; and plant density 3 where two rows of maize, $0.3 \mathrm{~m}$ apart, were planted using two seeds per hill at $0.375 \mathrm{~m}$ intra-row spacing, giving 88,888 plants ha ${ }^{-1}$.

The three maize intercrop populations with sweetpotato varieties were laid out following a modification of a design by Webi (2007). The sole maize check plots were planted in rows at spacings of $0.75 \mathrm{~m}$ by $0.3 \mathrm{~m}$, giving rise to 44,444 plants $\mathrm{ha}^{-1}$. A randomised complete block design (RCBD), with four replications, was used.

One month after planting, a blanket fertiliser was applied to all plots to invigorate plants, especially for maize. In the first season, N: P: K $(17: 17: 17)$ fertiliser was applied at a rate of $50 \mathrm{~kg}$ $\mathrm{ha}^{-1}$; while in the second season, $\mathrm{N}, \mathrm{P}$ and $\mathrm{K}$ were applied singly as urea, triple superphosphate and muriate of potash at rates of 50,50 and $60 \mathrm{~kg}$ $\mathrm{ha}^{-1}$ for $\mathrm{N}, \mathrm{P}_{2} \mathrm{O}_{5}$ and $\mathrm{K}_{2} \mathrm{O}$, respectively. The method in the second year enabled application of specific rates of the individual elements following recommendations from Makerere University, after analysing soil samples from the site. The plots were kept weed free through regular manual weeding.

A net plot measuring $2.4 \mathrm{~m} \mathrm{x} 4.2 \mathrm{~m}$ [determined by excluding the two outer ridges $(2.4 \mathrm{~m})$ and one extreme plant on either side of the inner ridges] was used to collect data at harvest. At 86 days after planting (DAP), the sweetpotato canopy had fully developed and leaf area index (LAI) was determined in all plots using the LAI-2200 Plant Canopy Analyser, from randomly chosen positions within each plot; while facing in the same direction as described in the operating manual (LI COR, 2010). Using the optical sensor, two readings above and four below the canopy (as recommended) were taken in each plot. The sensor was covered with a $90^{\circ}$ opaque view cap to restrict the operator and untargeted area from the lens view (LI COR, 2010).

Readings were taken between 3:30-5:30 pm under a clear sky. At 120 DAP, maize was harvested and data on grain yield collected after drying. At 135 DAP, sweetpotato was also harvested by uprooting all the plants in the net plot and number of plants harvested recorded. Roots and vines weights from each plot were also recorded. A sample of five roots with no physical damage, weighing 100 to $300 \mathrm{~g}$, was taken for dry matter and $\beta$-carotene determination. The roots were washed and rinsed with abundant tap water, peeled, and rinsed again using distilled de-ionised water. Each root was cut longitudinally into four quarter sections, and two opposite sections sliced using stainless steel blades, to obtain a $100 \mathrm{~g}$ compound sample that was placed in transparent polythene bags, and freeze dried at $-31{ }^{\circ} \mathrm{C}$ for 72 hours. Dry samples were weighed, milled into flour in a stainless steel mill, and stored in Kraft paper bags. Percent root dry matter was determined as a ratio of dry to fresh weights.

$\beta$-carotene in the milled samples of freezedried roots was measured with the near-infrared reflectance spectroscopy (NIRS) technology (Shenk and Westerhaus, 1993). Each milled sample material (two times $3 \mathrm{~g}$ ), was analysed by NIRS within the range of 400 to $2500 \mathrm{~nm}$, on a NIRS monochromator model 6500 (NIRSystems, Inc. Silver spring, MD); using small ring cups with sample autochanger. Near-infra-red spectra 
of each sample were used to determine $\beta$-carotene with the latest calibration version for sweetpotato freeze dried samples. In this version, the correlations in cross-validation between standard laboratory reference methods and NIRS are 0.97 for $\beta$-carotene (Zum Felde et al., 2009). The reference method for NIRS calibration was high performance liquid chromatography (HPLC) according to Rodriguez-Amaya and Kimura (2004) for $\beta$-carotene. Values of $\beta$-carotene content in the roots were used to determine $\beta$ carotene yield (metric tonnes per hectare) as follows:

$Y=\frac{t}{s} \mathrm{xd}$

Where:

$\mathrm{Y}=\beta$-carotene yield in $\mathrm{tha}^{-1}$;

$t=\beta$-carotene content in roots of the corresponding sole or intercrop treatments in $\mathrm{t} \mathrm{ha}^{-1}$;

$s=$ dry weight of the test samples $\left(\mathrm{t} \mathrm{ha}^{-1}\right)$ equal to 0.0001 for all treatment root samples; and $d=$ dry weight of total root yield $\left(\mathrm{t} \mathrm{ha}^{-1}\right)$.

Biomass was obtained as fresh weights of vines and roots per unit area. The Harvest Index was calculated to ascertain the main organs of assimilate allocation in the sweetpotato plant in all treatments.

Data were subjected to Analysis of Variance (ANOVA) using SAS Version 9.0. Percentage data were arc-sine transformed to stabilise variances. Treatment means were separated using Least Significant Difference (LSD) at $\alpha<0.05$. The land use efficiency was assessed using the Land Equivalent Ratio (LER) according to Mead and Willey (1980).

\section{RESULTS}

Leaf Area Index (LAI). LAI results are shown in Table 1. Seasonal differences, cropping systems and genotypes were all significant $(\mathrm{P}<0.05)$ for LAI. Overall, LAI was higher in season two (3.80) than in season one (2.66). LAI means for SPMaize density 1 and sole sweetpotato were significantly lower than sweetpotato-maize densities 2 and 3. Irrespective of the cropping system and season, Ejumula had higher LAI means than NASPOT 9 O.

Yield and harvest index (HI). Results for sweetpotato root and biomass yields, and harvest index (HI) are shown in Table 1. Seasonal effects were significant for root yield and HI, but not for biomass yield. Differences in cropping systems were, however, significant for root yield and biomass yield, but not for HI. For both root yield and biomass yield, a clear decreasing trend was observed across the cropping systems, being highest for sole sweetpotato crop (i.e., 12.2 $\mathrm{t} \mathrm{ha}^{-1}$ for root yield and $42.0 \mathrm{t} \mathrm{ha}^{-1}$ for biomass yield); and lowest for SP-Maize density 3 (i.e., $4.5 \mathrm{t} \mathrm{ha}^{-1}$ for root yield and $19.0 \mathrm{t} \mathrm{ha}^{-1}$ for biomass yield). Reductions in root and biomass yields revealed a better picture of the declining trend in the two parameters, as a result of increasing maize plant densities in the sweetpotato intercrops. For example, sweetpotato root yield reductions of $36.7,40$ and $62.5 \%$ were obtained at SP-maize densities 1, 2 and 3, respectively. For biomass yields, reductions of $32.6,32.1$ and $54.8 \%$ occurred at SP-maize densities 1, 2 and 3, respectively.

The HI of sweetpotato across cropping systems did not vary significantly. Thus, the proportion of roots in reference to total biomass was not significantly affected by the cropping systems. Sweetpotato genotype differerences were significant for root yield and HI, but not for biomass yield. NASPOT $9 \mathrm{O}$ had higher root yields and $\mathrm{HI}$ than Ejumula.

Dry matter, $\boldsymbol{\beta}$-carotene content and yield. The results for sweetpotato root dry matter content, $\beta$-carotene content and $\beta$-carotene yield are shown in Table 2. Season effects were not significant for $\beta$-carotene content, but significant for dry matter and $\beta$-carotene yield. A significant difference in dry matter was observed across the SP-Maize intercrop densities with SP-Maize density 3 having the highest dry matter content (33.0\%) and sole sweetpotato the lowest (32.2\%). $\beta$-carotene content varied significantly across cropping systems, being highest in the sole

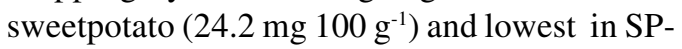
Maize density $3\left(20.3 \mathrm{mg} 100 \mathrm{~g}^{-1}\right)$. There were higher $\beta$-carotene yields in season 2 than season 
TABLE 1. The effect of season, cropping system and varieties on growth and yields of orange-fleshed sweetpotato in northern Uganda

\begin{tabular}{|c|c|c|c|c|}
\hline Factors of variation & LAl & Root yield $\left(\mathrm{t} \mathrm{ha} \mathrm{C}^{-1}\right)$ & Biomass yield $\left(\mathrm{t} \mathrm{ha}{ }^{-1}\right)$ & $\mathrm{HI}(\%)$ \\
\hline \multicolumn{5}{|l|}{ (a) Seasons } \\
\hline Season 1 & 2.66 & 6.4 & 28.0 & 24.0 \\
\hline Season 2 & 3.80 & 9.4 & 30.9 & 29.2 \\
\hline Mean & 3.23 & 7.9 & 29.4 & 26.6 \\
\hline $\operatorname{LSD}(0.05)$ & 0.20 & 1.5 & NS & 4.8 \\
\hline CV (\%) & 12.50 & 37.0 & 26.1 & 35.9 \\
\hline \multicolumn{5}{|l|}{ (b) Cropping system } \\
\hline SP sole & 3.02 & 12.2 & 42.0 & 28.8 \\
\hline SP-Maize density 1 & 3.06 & 7.6 & 28.3 & 26.4 \\
\hline SP-Maize density 2 & 3.47 & 7.2 & 28.5 & 26.3 \\
\hline SP-Maize density 3 & 3.36 & 4.5 & 19.0 & 24.9 \\
\hline Mean & 3.23 & 7.9 & 29.4 & 26.6 \\
\hline $\operatorname{LSD}(0.05)$ & 0.29 & 2.1 & 5.5 & NS \\
\hline CV $(\%)$ & 12.50 & 37.0 & 26.1 & 35.9 \\
\hline \multicolumn{5}{|l|}{ (c) SP genotypes } \\
\hline Ejumula & 3.54 & 5.1 & 30.2 & 16.8 \\
\hline NASPOT 90 & 2.92 & 10.6 & 28.7 & 36.4 \\
\hline Mean & 3.23 & 7.9 & 29.4 & 26.6 \\
\hline $\operatorname{LSD}(0.05)$ & 0.20 & 1.5 & NS & 4.8 \\
\hline CV $(\%)$ & 12.50 & 37.0 & 26.1 & 35.9 \\
\hline
\end{tabular}

NS = not significant at $P<0.05$

1. $\beta$-carotene yields varied significantly across cropping systems, being higher in the sole sweetpotato crops than any of the SP-maize densities, but showed a declining trend with increasing maize plant density in the intercrop.

Genotypes were significantly different for root dry matter, $\beta$-carotene content and $\beta$ carotene yield. Ejumula had higher dry matter content (33.5\%) and $\beta$-carotene content $(23.2 \mathrm{mg}$ $\left.100 \mathrm{~g}^{-1}\right)$ than NASPOT $90(31.5 \%$ and $21.1 \mathrm{mg}$ $100 \mathrm{~g}^{-1}$, respectively). However, NASPOT $9 \mathrm{O}$ had higher $\beta$-carotene yields than Ejumula because of the higher root yield per area.

Grain yield. Maize grain yield obtained for different treatments and seasons are shown in Table 3. Unlike sweetpotato root yields, there were no significant season effects on maize grain yield. Instead maize grain yield varied across the different maize plant densities, being significantly higher for the sole maize crop (5.4 $\left.\mathrm{t} \mathrm{ha}^{-1}\right)$ than each of the other intercrop treatments. The grain yield means for SP-maize density $1\left(3.4 \mathrm{tha}^{-1}\right), 2$ $\left(3.8 \mathrm{t} \mathrm{ha}^{-1}\right)$, and $3\left(4.0 \mathrm{t} \mathrm{ha}^{-1}\right)$ were not significantly different.

Land use efficiency by the intercrops. The partial LERs were generally higher in maize than in sweetpotato (Table 4). Sweetpotato partial LER in density 3 (0.37) was considerably low, denoting a substantial yield reduction of sweetpotato in density 3. The LERs in all the cropping systems, however, were greater than 1 .

\section{DISCUSSION}

The higher LAIs during season 2 (Table 1) are probably due to more favourable weather 
TABLE 2. The effect of season, cropping system and varieties on dry matter, $\beta$-carotene content and yield in orange-fleshed sweetpotato in northern Uganda

Factors of variation $\quad$ Dry matter $(\%) \quad \beta$-carotene content $\left({\left.\mathrm{mg} 100 \mathrm{~g}^{-1}\right)}^{-1} \quad \beta\right.$-carotene yield(t ha-1)

\section{(a) Seasons \\ Season 1}

Season 2

Mean

$\operatorname{LSD}(0.05)$

CV\%

\section{(b) Cropping system}

SP sole

SP-Maize density 1

SP-Maize density 2

SP-Maize density 3

33.6
31.4

32.5
0.5
3.0

22.2

22.1

22.2

NS

17.2

$4.2 \times 10^{-4}$

$5.6 \times 10^{-4}$

$4.9 \times 10^{-4}$

$1 \times 10^{-4}$

43.9

$\begin{array}{lrll}\text { Mean } & 32.5 & 22.2 & 4.9 \times 10^{-4} \\ \text { LSD }(0.05) & 0.7 & 2.7 & 2.0 \times 10^{-4} \\ \text { CV } \% & 3.0 & 17.2 & 43.9 \\ & & & \\ \text { (c) SP genotypes } & 33.5 & 23.2 & 3.8 \times 10^{-4} \\ \text { Ejumula } & 31.5 & 21.1 & 6.1 \times 10^{-4} \\ \text { NASPOT 9 0 } & & & 4.9 \times 10^{-4} \\ \text { Mean } & 32.5 & 22.2 & 1.0 \times 10^{-4} \\ \text { LSD }(0.05) & 0.5 & 1.9 & 43.9 \\ \text { CV } \% & 3.0 & 17.2 & \end{array}$

TABLE 3. Maize grain yield across different sweetpotato (SP) - maize intercropping systems in northern Uganda

Factor of variation $\quad$ Grain yield $\left(t\right.$ ha $\left.^{-1}\right)$

\section{(a) Seasons}

Season 1

Season 2

4.0

4.3

Mean

$\operatorname{LSD}(0.05)$

CV $(\%)$

4.1

NS

25.0

(b) Cropping system

SP-Maize density 1

SP-Maize density 2

SP-Maize density 3

Maize sole

Mean

$\operatorname{LSD}(0.05)$
TABLE 4. The Land Equivalent Ratio (LER) of sweetpotato intercropped with maize in the three plant densities in northern Uganda

\begin{tabular}{lccc}
\hline Cropping system & Sweetpotato & Maize & LER \\
\hline SP-Maize density 1 & 0.62 & 0.63 & 1.24 \\
SP-Maize density 2 & 0.59 & 0.70 & 1.23 \\
SP-Maize density 3 & 0.37 & 0.73 & 1.1 \\
\hline
\end{tabular}

CV $(\%)$ 
conditions (data not presented). Situations of limited moisture have been reported (XoconostleCázares et al., 2011, Hajibabaee et al., 2012) to impair plant growth and cause plants to reduce their foliar area to lessen water loss. Also, leaf growth was found to be severely inhibited at the onset of drought (Chaves et al., 2003), and more severe effects were observed in maize which is more sensitive to harsh weather conditions (Aslam et al., 2013).

The increasing trends of LAI from the sole sweetpotato crop to increasing maize plant densities in the intercrop treatments is possibly due to the increasing number of maize plants. Similarly, Jamshidi et al. (2008) reported increases in the LAI with increasing maize density in a maize potato intercrop in Iran. The higher LAI values were a result of the collective sum of leaf coverage of the two crops (sweetpotato and maize). The higher LAI observed in Ejumula-maize intercrops than NASPOT 9 O-maize intercrops, confirms that Ejumula is genetically more vegetative than NASPOT $9 \mathrm{O}$, an observation previously made by Mwanga et al., 2007; 2009) and Tumwegamire et al. (2014).

Like LAI, the higher root yields and HI in season 2 (Table 1) are again probably due to favorable weather conditions experienced in season two than in season one. Villareal and Hsu (1982), and Byamukama et al. (2007) reported variation in sweetpotato root yields across seasons and attributed it to seasonal weather variations. The decline in root and biomass yields observed in the present study, with the increasing maize plant populations, is in agreement with previous studies on sweetpotato (Egbe and Idoko, 2009; Ossom, 2010) and potatoes (Ebwongu et al, 2001). While studying sweetpotato-pigeonpea intercropping, Egbe and Idoko (2009) observed declining fresh root yield across five sweetpotato varieties. The decline was attributed to reduced photosynthesis by sweetpotato leaves, due to reduced solar radiation interception by shading from the taller pigeonpea plants. Similarly, in the potato-maize mixture, increase in maize plant population resulted in a decline in tuber yield (Ebwongu et al., 2001), due to reduced light interception by the potato hence the reduced photosynthetic activities of the crop. Apart from light, crops grown in association compete for water and nutrients in the soil (Oroka and Omoregie, 2007), and high plant densities result in increased competition for these resources, consequently causing low yields (Zamir et al., 2011).

Under induced shade conditions, Sale (1976) and Oswald et al. (1995a), respectively, studied potato and sweetpotato and all reported decreased numbers and bulking rate of potato tubers and sweetpotato roots, and hence, subsequent yield reductions. In potato, shade was reported to reduce potato cell proliferation and cell volume, resulting in a decline in fresh weight. This is because cell proliferation is positively correlated to plant photosynthetic status (Chen and Setter, 2003). On the other hand, shade on sweetpotato in the last stages of growth, has a more negative effect on root yield, than during the early stages of development (Oswald et al., 1995b). Thus, sweetpotato can best tolerate other crops up to the third month, beyond which root yields will decline severely.

Lack of variation in HI across cropping systems (Table 1) denotes the potential of sweetpotato to maintain a balance between the shoot and root biomasses in varying intercrop densities. Heuvel et al. (2004) noted that the root:shoot ratio decreases with increasing shade, and Valenzuela et al. (1991) reported that increased shading in cocoyam resulted in an increase in plant top:corm ratio a situation that did not manifest in our study.

The two study sweetpotato varieties exhibited marked differences for root yield (Table 1), but were similar for total biomass yield. NASPOT 90 showed higher root yield potentials than Ejumula, a result previously reported by Mwanga et al. (2007; 2009) for several sites. Inherent differences in yielding potentials and yield stability, known to exist between varieties (Kapinga et al., 2010), can explain the consistent and significant differences in root yields observed between NASPOT 90 and Ejumula in our study, even across the intercrop populations of maize. Variations in root yield potentials between varieties may arise due to differences in assimilate partitioning, which mainly depends on the sink strength, which in turn depends on sink size and sink activity/intensity (Marcelis, 1996; Yang et $a l ., 2003)$. The roots as a sink seem to have been 
weak in attracting assimilates in Ejumula than in NASPOT $9 \mathrm{O}$, contributing a greater percentage of low root yields in the former. Differences in HI, observed across varieties in our study, are in agreement with previous studies (Bhagsari and Ashley, 1990).

The higher HI in NASPOT 9 O compared to Ejumula is associated with the high root yielding potential of the former than the latter (Tumwegamire et al., 2014). As noted earlier, Ejumula has more vegetation, which probably disadvantages its root yield potential. As observed by Lemaga (1992), when a plant has many leaves, not all are able to effectively photosynthesize due to such factors as internal shading, hence, some of the leaves become sinks rather than source organs.

The genetic differences between varieties could bear varied implications in the final usage and the seed systems of the two varieties. For example, Ejumula could be recommended in farming systems that, on top of producing roots for food, demand foliage for livestock feeding. For the same reasons, Ejumula can be a useful parent in a breeding programme to develop dual purpose varieties for farming systems that demand both roots and foliage. Additionally, more seed vines can be obtained per unit area from Ejumula than NASPOT 90 in a vine multiplication system.

Significant increases in dry matter content across the sweetpotato-maize intercrop densities (Table 2), were observed, implying that intercropping and increasing maize plant densities increases root dry matter content of sweetpotato. Root dry matter content was lowest $(32.2 \%)$ in sole sweetpotato and highest (33\%) in SP-Maize density 3. This finding, contradicts a previous study by Ebwongu et al. (2001), where reduction in potato tuber dry matter content due to intercropping was reported. Also, Ennin et al. (2002) reported decreasing dry matter of soybean (Glycine max Merril) and maize plants with excess moisture availability. The explanation for the divergence of our study from previous ones is not clear and merits further investigation.

$\beta$-carotene levels did not vary significantly between seasons, but between sweetpotatomaize intercrop densities, with a decreasing trend (Table 2). The lower $\beta$-carotene contents observed at the highest maize plant density in the intercrop, are probably due to shading effect on sweetpotato crop by maize plants. Carotenoid compositions have previously been reported to decrease in leaves of yam (Dioscorea zingiberensis) at low light intensities (Li et al., 2002). Grumbach and Lichtenthaler (1982) reported that carotenoid biosynthesis was increased by light, while Simkin et al. (2003), found that in prolonged dark conditions, carotenoid biosynthesis is completely cut off in pepper (Capsicum annuum) leaves.

Apart from light or shade, some studies have reported the effect of varying environmental factors on the $\beta$-carotene levels in the sweetpotato roots (Andrade et al., 2009); while others (Gruneberg et al., 2005; Tumwegamire et $a l ., 2011)$ reported very low effects on $\beta$-carotene content in sweetpotato by environmental factors. Gruneberg et al. (2009) explained that environment factors have low influences on majority of quality traits in crops. To validate our findings, the effect of shading on the levels of $\beta$ carotene in sweetpotato under controlled conditions merits further investigation.

$\beta$-carotene yields followed the same declining trends as observed for the root yields across increasing maize intercrop plant densities (Table 2 ). Moreover, $\beta$-carotene yield values were calculated using dry root yield and $\beta$-carotene content values. $\beta$-carotene in foods is an important precursor for vitamin $\mathrm{A}$ in the human body, and the observed decline trends imply negatively on the consumers nutrition security.

In this study, maize grain yield did not vary with seasons, but showed declining trends under intercropping systems with sweetpotato (Table 3 ). Previous studies have similarly reported reduction in maize grain yields from intercropping systems with soybean and climbing beans (Ennin et al., 2002; Niringiye et al., 2005).

From this study, increasing maize plant densities in intercrops seem to compensate for yield reductions, due to intercropping compared to the sole crop. For example, at sweetpotatomaize density 3 , grain yield was only $25.9 \%$ less than that of sole crop, improving from $37 \%$ yield decline at sweetpotato-maize density 1 . It is likely that the compensation effect has a limit after which it starts to decline. Sarlak et al. (2008) reported 
that increasing maize plant density beyond the optimum causes yield decline; while lower plant densities exhibit higher yields. Optimum maize plant density for maximum economic grain yield varies from 30,000 to over 90,000 plants ha $^{-1}$ depending on water availability, soil fertility, maturity time, planting date and spacing (Olson and Sanders, 1988). This implies that increasing the maize population to 88,888 plants ha $^{-1}$ (i.e., plant density 3 ) was not necessary since it caused no grain yield gain. Moreover, at sweetpotatomaize density 3 , the root yields were reduced by $63 \%$, hence, a lower maize population $(55,555$ plants $\mathrm{ha}^{-1}$ ) that allows a higher sweetpotato yield in the intercrop would be most preferred.

Land Equivalent Ratios above 1 were obtained for all the intercrop systems (Table 4), indicating that intercropping was more efficient than sole cropping. Previous studies also showed yield advantages in maize/sweetpotato intercrops (Oswald et al., 1996; Ossom et al., 2009). Nevertheless, density 3 which had the highest maize population, had the lowest LER (1.1), indicating a negative interaction between sweetpotato and maize. This could have been mainly due to competition suffered by sweetpotato, which is a shorter crop than maize, resulting into the least partial LER at density 3; while that of maize increased. Muoneke and Mbah (2007) obtained similar results in cassava-okra intercrop, where the combination with the highest okra population had the least LER for cassava. Considering intercrop densities 1 and 2, the area planted to sole crops would need to be greater than the area under intercrops by 24 and 23\%, respectively, for the two crops to produce the same combined yields as the yields from the intercrops. This clearly illustrates that intercrop densities 1 and 2 performed better than the sole crops and intercrop density 3 , and are thus suitable levels for sweetpotato-maize intercropping systems.

The higher partial LERs for maize compared with sweetpotato, in all intercrop densities, suggest that sweetpotato/maize intercropping caused a higher yield reduction in sweetpotato than in maize, probably due to higher competitive ability of maize than sweetpotato. Maize, a $\mathrm{C}_{4}$ and taller crop, in the mixture stood the advantage of fully capturing and utilising sunlight; while sweetpotato which is a $\mathrm{C}_{3}$ plant and less efficient in carbon assimilation; was shaded by maize, hence, affecting its effective photosynthetic rates, which in turn was manifested in low root bulking rates. $\mathrm{C}_{4}$ plants have an advantage for carbon fixation at high light intensities because of the high light saturation point (Skillman, 2008).

The results imply that at higher maize population in the intercrop, sweetpotato is outcompeted for light, with the resultant significant root yield reductions. In a maize-bean intercropping experiment, Tsubo et al. (2004) did not observe reduction in maize yields, and maize was a more aggressive crop in the mixture. Also, Oswald et al. (1996) reported that the partial LER of maize in a sweetpotato-maize intercrop contributed largely to the total LER depending on the location where the experiment was set.

\section{CONCLUSION}

There are yield advantages from sweetpotatomaize intercropping systems in Uganda. The intercrop maize populations of 41,666 (density 1) and 55,555 (density 2) plants ha ${ }^{-1}$ give higher yields of the two crops than sole sweetpotato and maize populations, and are recommended to give farmers meaningful yield gains from the two nutritious crops, having diets rich in both vitamin A and proteins; while making better use of land and labour. Unfortunately, the same intercropping systems seem to affect root content of $\beta$-carotene in sweetpotato, i.e. $\beta$-carotene reduces with increasing intercropping plant populations. Maize plants reduce light interception by the sweetpotato, which results in reduced $\beta$-carotene biosynthesis, and hence, its content in the roots. However, we recommend that varieties with relatively high $\beta$-carotene be selected for intercropping and that lower plant densities of the component crop, especially the tall and aggressive crops, should be used to minimise shading on the growing sweetpotato. Further studies need to be conducted under controlled experiments to elucidate the effect of shading on $\beta$-carotene content in sweetpotato roots. This study further confirms the high yielding potential of variety NASPOT $9 \mathrm{O}$ compared to Ejumula and illustrates that NASPOT $9 \mathrm{O}$ performs better than Ejumula when intercropped with maize. 


\section{ACKNOWLEDGEMENT}

The research was accomplished under DONATA (Dissemination of New Agricultural Technologies in Africa) project implemented by the International Potato Centre (CIP) and funded by the Forum for Agricultural Research in Africa (FARA), through Association for Strengthening Agricultural Research in East and Central Africa (ASARECA). CIP supplemented the research funds.

\section{REFERENCES}

Andrade, M., Barker, I., Cole, D., Dapaah, H., Elliott, H., Fuentes, S., Grüneberg, W., Kapinga, R., Kroschel, J., Labarta, R., Lemaga, B., Loechl, C., Low, J., Lynam , J., Mwanga, R., Ortiz, O., Oswald, A. and Thiele, G. 2009. Unleashing the potential of sweetpotato in Sub-Saharan Africa: Current challenges and way forward. International Potato Center (CIP), Lima, Peru. Working Paper 2009-1. 197p.

Aslam, M., Zamir, M.S.I., Afzal, I., Yaseen, M., Mubeen, M. and Shoaib, A. 2013. Drought stress, its effect on maize production and development of drought tolerance through potassium application. Cercetãri Agronomice în Moldova 46:99-114

Bashaasha, B., Mwanga, R.O.M., Ocitti p'Obwoya, C. and Ewell, P.T. 1995. Sweetpotato in the farming and food systems of Uganda: A Farm Survey Report. International Potato Center, Sub- Saharan Africa Region, Nairobi, Kenya. pp. 1-63.

Bhagsari, A.S. and Ashley, D.A. 1990. Relationship of photosynthesis and harvest index to sweet potato yield. Journal of the American Society for Horticultural Science 15(2):288-293.

Byamukama, E., Gibson, R.W., Mpembe, I., Kayongo, J. and Mwanga, R.O.M. 2007. Effect of shade and intercropping in the management of sweetpotato virus disease in Uganda. Proceedings of the 13th ISTRC Symposium, 2007. pp. 233 - 239.

Chaves, M.M., Maroco, J.P. and Pereira, J.S. 2003. Understanding plant responses to droughtfrom genes to the whole plant. Functional Plant Biology 30:239-264.
Chen, C. and Setter, T.L. 2003. Response of potato tuber cell division and growth to shade and elevated $\mathrm{CO}_{2}$. Annals of Botany 91: 373-381.

Ebwongu, M., Adipala, E., Ssekabembe, C.K., Kyamanywa, S. and Bhagsari, A.S. 2001. Effect of intercropping maize and Solanum potato on yield of the component crops in Central Uganda. African Crop Science Journal 9(1): 83-96.

Egbe, O.M. and Idoko, J.A. 2009. Agronomic assessment of some sweetpotato varieties for intercropping with pigeonpea in Southern Guinea Savanna of Nigeria. Journal of Tropical Agriculture, Food, Environment and Extension 8 (2): 74- 83.

Ennin, S.A., Clegg, M.D. and Francis, C.A. 2002. Resource utilization in soybean/maize intercrops. African Crop Science Journal 10(3): 251-261.

FAO, 2010. Nutrition country profile. The Republic of Uganda. Food Insecurity and Vulnerability Information and Mapping Systems. ftp://ftp.fao.org/ag/agn/nutrition/ ncp/uga.pdf. Accessed on 22 October, 2015.

Frossard, E., Bucher, M., Machler, F., Mozafar, A. and Hurrell, R. 2000. Review: Potential for increasing the content and bioavailability of $\mathrm{Fe}, \mathrm{Zn}$ and $\mathrm{Ca}$ in plants for human nutrition. Journal of the Science of Food and Agriculture 80(7): 861 - 879.

Gibson, R.W. 2006. Crop protection programme. Extending control of sweet potato diseases in East Africa R8457 (ZA0681). Final technical report. University of Greenwich, Natural Resources Institute, Chatham Maritime, Kent. ME4 4TB, UK.

Grumbach, K.H. and Lichtenthaler, H.K. 1982. Chloroplast pigments and their biosynthesis in relation to light intensity. Photochem Photobiol 35: 209-212.

Gruneberg, W.J., Manrique, K., Zhang, D. and Hermann, M. 2005. Genotype x environment interactions for a diverse set of sweetpotato clones evaluated across varying ecogeographic conditions in Peru. Crop Science 45: 2160-2171.

Gruneberg, W.J., Mwanga, R., Andrade, M. and Espinoza, J. 2009. Selection methods Part 5: Breeding clonally propagated crops. pp. 275- 
322. In: Ceccarelli, S., Guimaraes, E.P. and Weltzien, E. (Eds.). Plant breeding and farmer participation, FAO, Rome, Italy.

Hajibabaee, M., Azizi, F. and Zargari, K. 2012. Effect of drought stress on some morphological, physiological and agronomic traits in various foliage corn hybrids. American-Eurasian Journal of Agricultural \& Environmental Sciences 12 (7): 890-896.

Heuvel, J.E.V., Proctor, J.T.A., Fisher, K.H. and Sullivan, J.A. 2004. Shading affects morphology, dry matter partitioning, and photosynthetic response of greenhousegrown 'Chardonnay' Grapevines. Hort Science 39(1): 65-70.

Internatinal Potato Center (CIP). 2015. http:// cipotato.org/research/sweetpotato-in-africa. Accessed on 24 ${ }^{\text {th }}$ April 2015.

Jamshidi, K., Mazaheri, D. and Saba, J. 2008. An evaluation of yield in intercropping of maize and potato. Desert 12:105-111.

Kapinga, R., Tumwegamire, S., Ndunguru, J., Andrade, M.I., Agili, S., Mwanga, R.O.M., Laurie, S. and Dapaah, H. 2010. Catalogue of orange-fleshed sweetpotato varieties for SubSaharan Africa. International Potato Center (CIP), Lima, Peru. 40p.

Krivanek, A.F., De Groote, H., Gunaratna, N.S., Diallo, A.O. and Friesen, D. 2007. Breeding and disseminating quality protein maize (QPM) for Africa. African Journal of Biotechnology 6(4): 312-324.

Lemaga, B. 1992. Daylength and main stem number effects on yield components and tuber yield of potatoes (Solanum tubersum L.) cv. Erntestolz. Ethiopian Journal of Agricultural Science 13: 9-20.

LI COR, 2010. LAI-2200 Plant Canopy Analyzer. Operating Manual. LI-COR, Inc. Publication No. 984-10633.Lincoln, NE USA.

Li, H., Radunz, A., He, P. and Schmid, G.H. 2002. Influence of different light intensities on the content of diosgenin, lipids, carotenoids and fatty acids in leaves of Dioscorea zingiberensis. Zeitschrift für Naturforschung C 57c:135-143.

Lithourgidis, A.S., Dordas, C.A. and Damalas, C.A. 2011. Vlachostergios DN, Annual intercrops: an alternative pathway for sustainable agriculture. African Crop Science Journal 5(4): 396-410.

Low, J. W., Arimond, M., Osman, N., Cunguara, B., Zano, F. and Tschirley, D. 2007. Seeking sustainable health improvements using orange-fleshed sweet potato. LEISA Magazine 23.3.

Low, J., Walker, T. and Hijmans, R. 2001. The potential impact of orange-fleshed sweetpotatoes on vitamin A intake in SubSaharan Africa. Paper presented at a regional workshop on food-based approaches to human nutritional deficiencies The VITAA Project, vitamin A and orange-fleshed sweetpotatoes in Sub-Saharan Africa 9-11 May 2001, Nairobi, Kenya

Marcelis, L.F.M. 1996. Sink strength as a determinant of dry matter partitioning in the whole plant. Journal of Experimental Botany 47: 1281-1291.

Mead, R. and Willey, R.W. 1980. The concept of a land equivalent ratio and advantages in yields from intercropping. Experimental Agriculture 16: 217-228.

Muoneke, C.O. and Mbah, E.U. 2007. Productivity of cassava/okra intercropping systems as influenced by okra planting density. African Journal of Agricultural Research 2(5): 223-231.

Mwanga, R.O.M., Odongo, B., Niringiye, C., Alajo, A., Kigozi, B., Makumbi, R., Lugwana, E., Namukula, J., Mpembe, I., Kapinga, R., Lemaga, B., Nsumba, J., Tumwegamire, S. and Yencho, C.G. 2009. 'NASPOT 7', 'NASPOT 8', 'NASPOT 90 ', 'NASPOT 10 O', and 'Dimbuka-Bukulula' Sweetpotato. Hort Science 44(3): 828-832.

Mwanga, R.O.M, Odongo, B., Niringiye, C., Alajo, A., Abidin, P. E., Kapinga, R., Tumwegamire, S., Lemaga, B. and Nsumba, J. 2007. Carey, EE, release of two orange-fleshed sweetpotato cultivars, 'SPK004' ('Kakamega') and 'Ejumula', in Uganda. HortScience 42(7):1728-1730.

Niringiye, C.S., Ssekabembe, C.S. and Kyamanywa, S. 2005. Effect of plant population on yield of maize and climbing beans grown in an intercropping system. African Crop Science Journal 13(1):83-93. 
Odongo, A., Lemaga, B., Kapinga, R., Tumwegamire, S. and Nsumba, J. 2007. Orange-fleshed sweetpotato as a disaster mitigation crop in war- torn northern Uganda. Proceedings of the $13^{\text {th }}$ ISTRC Symposium, 2007. pp. $795-800$.

Olson, R.A. and Sanders, D.H. 1988. Maize production. In: Sprague, G.F. and Dudley, J.W. (Eds.). Corn and corn improvement. Madison: American Society of Agronomy, Chap.11. pp. 639-678.

Oroka, F.O. and Omoregie, A.U. 2007. Competition in a rice-cowpea intercrop as affected by nitrogen fertilizer and plant population. Scientia Agricola 64(6): 621-629.

Ossom, E.M. 2010. Influence of sweet potato/ maize association on ecological properties and crop yields in Swaziland. International Journal of Agriculture and Biology 12: 481488.

Ossom, E.M., Kuhlase, L.M. and Rhykerd, R.L. 2009. Effects of plant population on yield components and yield of intercropped sweetpotato [Ipomoea batatas (L.) Lam.] and groundnut (Arachis hypogaea L.). AmericanEurasian Journal of A gronomy 2(1): 01-06.

Oswald, A., Alkämper, J. and Midmore, D.J. 1995a. The effect of different shade levels on growth and tuber yield of sweetpotato: II. Tuber Yield. Journal of Agronomy and Crop Science 175: 29-40.

Oswald, A., Alkämper, J. and Midmore, D.J. 1995b. Response of sweetpotato (Ipomoea batatas Lam.) to shading at different growth stages. Journal of Agronomy and Crop Science 175: 99-107.

Oswald, A., Alkämper, J. and Midmore, D.J. 1996. The Response of Sweetpotato (Ipomoea batatas Lam.) to Inter- and Relay-cropping with Maize (Zea mays L.). Journal of Agronomy and Crop Science 176: 275-287.

Rodriguez-Amaya, D.B. and Kimura, M. 2004. HarvestPlus handbook for carotenoid analysis. HarvestPlus Technical Monograph Series 2.

Sale, P.J.M. 1976. Effect of shading at different times on the growth and yield of the potato. Australian Journal of Agricultural Research 27(4): 557-566.
Sarlak, S., Aghaalikhani, M. and Zand, B. 2008. Effect of pant density and mixing ratio on crop yield in sweet corn/mungbean intercropping. Pakistan Journal of Biological Siences 11(17):2128-2133.

Shenk, J.S. and Westerhaus, M.O. 1993. Analysis of agriculture and food products by near infrared reflectance spectroscopy. The Pennsylvania State University and Infrasoft International, State College, PA.

Simkin, A.J., Uhu, C., Kuntz, M. and Sandmann, G. 2003. Light-dark regulation of carotenoid biosynthesis in pepper (Capsicum annuиm) leaves. Journal of Plant Physiology 160: 439443.

Skillman, J.B. 2008. Quantum yield variation across the three pathways of photosynthesis: not yet out of the dark. Journal of Experimental Botany 59(7): 1647-1661.

Tsubo, M., Ogindo, H.O. and Walker, S. 2004. Evaluation of maize-bean intercropping in a Semi-arid region of South Africa. African Crop Science Journal 12(4): 351-358.

Tumwegamire, S., Mwanga, R.O.M., Andrade, M.I., Low, J.W., Ssemakula, G.N., Laurie, S.M., Chipungu, F.P., Ndirigue, J., Agili, S., Karanja, L., Chiona, M., Njoku, J.C., Mtunda, K., Ricardo, J., Adofo, K., Carey, E. and Grüneberg, W.J. 2014. Orange-fleshed sweetpotato for Africa. Catalogue 2014 (Second Edition). International Potato Center (CIP) Lima, Peru. 74p.

Tumwegamire, S., Rubaihayo, P. R., LaBonte, D.R., Gruneberg, W. J., Kapinga, R. and Mwanga, R. O. M. 2011. Genotype x environment interactions for East African orange-fleshed sweetpotato clones evaluated across varying ecogeograhic conditions in Uganda, In: Tumwegamire, S. Genetic variation, diversity and genotype by environment interactions of nutritional quality traits in East African sweetpotato. PhD Thesis. Makerere University, Kampala, Uganda.

Tumwegamire, S., Kapinga, R., Zhang, D., Crissman, C. and Agili, S. 2004. Opportunities for promoting orange fleshed sweetpotato as a mechanism for combating vitamin A deficiency in Sub-Saharan Africa. African Crop Science Journal 12(3): 241-252. 
UBOS (Uganda Bureau of Statistics), 2007. Uganda Demographic and Health Survey 2006. Full Report. pp. 1-467.

Uganda Bureau of Statistics (UBOS) and ICF International Inc. 2012. Uganda Demographic and Health Survey 2011. Kampala, Uganda: UBOS and Calverton, Maryland: ICF International Inc.

Valenzuela, H.R., O'Hair, S.K. and Schaffer, B. 1991. Shading, growth, and dry-matter partitioning of cocoyam [Xanthosoma sagittifolium (L.) Schott]. Journal of the American Society for Horticultural Science 116(6): 1117-1121.

Van Jaarsveld, P.J., Faber, M., Tanumihardjo, S.A., Nestel, P., Lombard, C.J. and Benadé, A.J.S. 2005. $\beta$-Carotene-rich orange-fleshed sweet potato improves the vitamin A status of primary school children assessed with the modified-relative-dose-response test. American Journal of Clinical Nutrition 81:1080-7.

Vasal, S.K. 2001. Quality protein maize development: An exciting experience. Seventh Eastern and Southern Africa Regional Maize Conference. $11^{\text {th }}-15^{\text {th }}$ February, 2001. pp. 3-6.

Villareal, R.L. and Hsu, Y.M. 1982. Varietal responses of sweetpotato to relay cropping. Philippine Journal of Crop Science 7(3): 134-136.
Webi, P.O.W. 2007. Compatibility of sweet potato (Ipomoea batatas L .) and maize (Zea mays L.) under different intercropping patterns in western Kenya. A thesis submitted in M.Phil., in Agronomy. Moi University Eldoret, Kenya.

Xoconostle-Carzares, B., Ramirez-Ortega, F. A., Flores-Elenes, L. and Ruiz-Medrano, R. 2011. Drought tolerance in crop plants. American Journal of Plant Physiology. ISSN 1557-4539 / DOI: 10.3923/ajpp.

Yang, J., Zhang, J., Wang, Z. and Zhu, Q. 2003. Hormones in the grains in relation to sink strength and postanthesis development of spikelets in rice. Plant Growth Regul 41: 185-195.

Zamir, M.S.I., Ahmad, A.H., Javeed, H.M.R. and Latif, T. 2011. Growth and yield behaviour of two maize hybrids (Zea mays L.) towards different plant spacing. Cercetãri Agronomice în Moldova 14(2): 33-40.

Zum Felde, T., Burgos, G., Espinoza, J., Eyzaguirre, R., Porras, E. and Gruneberg, W. 2009. Screening for $\beta$-carotene, iron, zinc, starch, individual sugars and protein in sweetpotato germplasm by Near-Infrared Reflectance Spectroscopy (NIRS). 15 th Triennial Symposium of the International Society for Tropical Root Crops, Lima, Peru. November 2 - 9, 2009. http://r4d.dfid.gov.uk/PDF/ Outputs/Misc_Crop/s8_zumfelde.pdf 